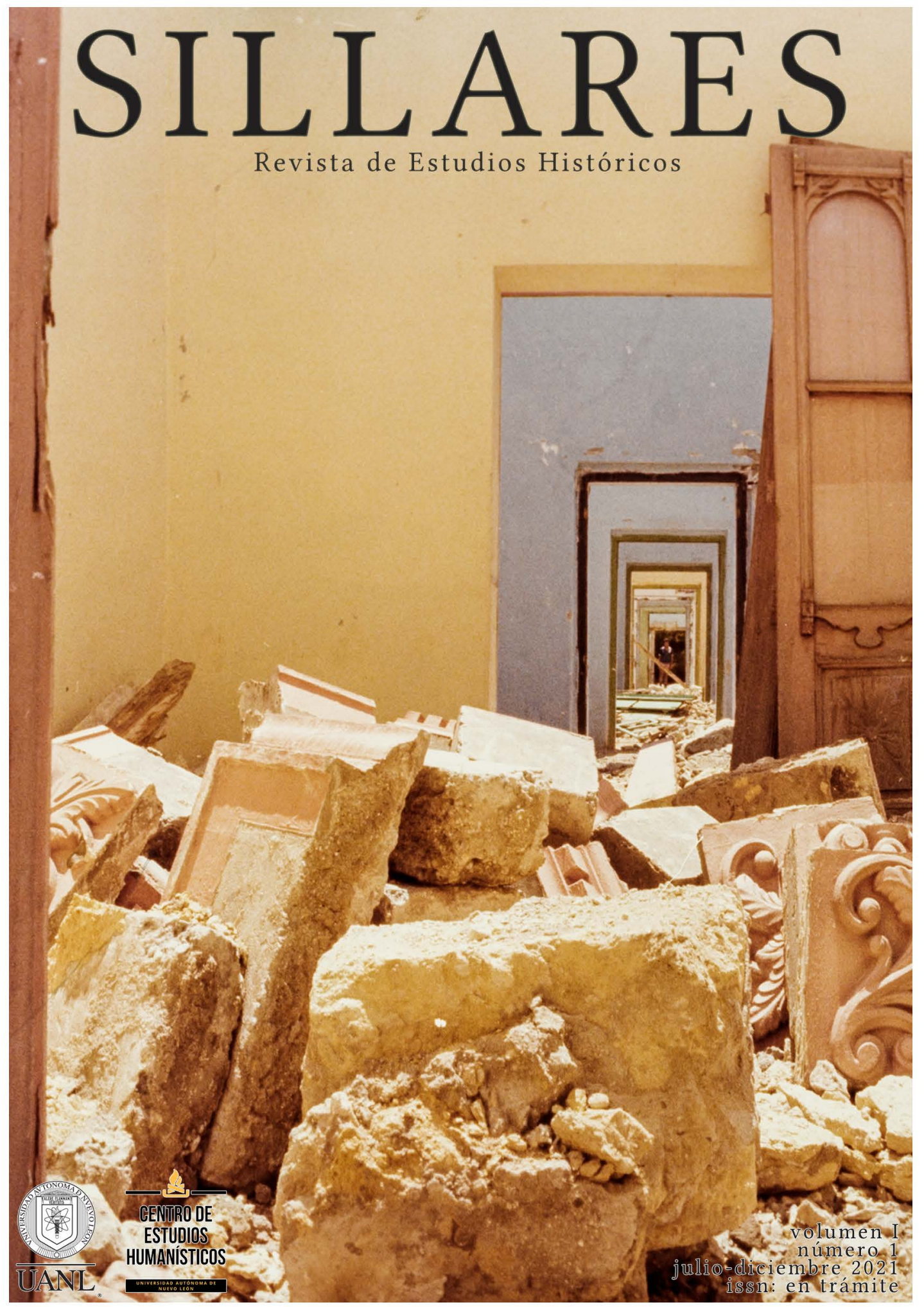


Rogelio G. Garza Rivera

Rector

Santos Guzmán López

Secretario General

Celso José Garza Acuña

Secretario de Extensión y Cultura

Humberto Salazar Herrera

Director de Historia y Humanidades

César Morado Macías

Titular del Centro de Estudios Humanísticos

José Eugenio Lazo Freymann

Director

Copyright: C 2021. Atribución-NoComercial-SinDerivadas 4.0 Internacional (CC BY-NC-ND 4.0).

ISSN en trámite

Sillares. Revista de Estudios Históricos es parte de Revistas UANL, proyecto de la Dirección de Tecnologías de Información, de la Coordinación de Sistemas para Bibliotecas, de la Subdirección de Sistemas Académicos. Teléfono: 818329-4105. Correo electrónico: revistas@uanl.mx.

Foto de portada: D.R. (C) Fototeca Nuevo León-CONARTE, Fondo: Fausto Tovar.

Centro de Estudios Humanísticos. Biblioteca Universitaria Raúl Rangel Frías, Av. Alfonso Reyes No. 4000 Nte. Col. Regina, C.P. 64290, Monterrey, Nuevo León, México. Teléfono: 8183294000 ext. $6533 . \quad$ Correo electrónico: historia.ceh@uanl.mx Sitio web: https://sillares.uanl.mx/index.php/s.

Derechos reservados. Se permite la reproducción parcial para fines académicos citando la fuente.

Impreso en Monterrey, Nuevo León, México. 


\title{
Sillares
}

Revista de Estudios Históricos

sillares.uanl.mx

\section{Inmigración y formación del empresariado libanés en Tampico durante la primera mitad del siglo $X X$}

\section{Immigration and formation of Lebanese businessmen in Tampico during the first half of the 20th century}

\author{
Oscar Israel Pizaña Grimaldo \\ El Colegio de San Luis \\ orcid.org//0000-0001-7851-2936
}

Recibido: 11 de diciembre de 2020

Aceptado: 17 de marzo de 2021

Publicado: 1 de julio de 2021

Copyright: (C) 2021, Pizaña Grimaldo Oscar Israel. This is an open-access article distributed under the terms of Creative Commons Attribution License [CC BY 4.0], which permits unrestricted use, distribution, and reproduction in any medium, provided the original author and source are credited.

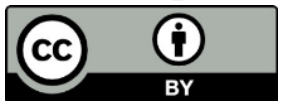

DOI: https://doi.org/10.29105/sillares1.1-2 


\title{
Inmigración y formación del empresariado libanés en Tampico durante la primera mitad del siglo XX
}

\author{
Immigration and formation of Lebanese businessmen in \\ Tampico during the first half of the $20^{\text {th }}$ century
}

Oscar Israel Pizaña Grimaldo

El Colegio de San Luis

orcid.org/0000-0001-7851-2936

Resumen: En este artículo examino la inmigración y la formación del empresariado libanés en Tampico, Tamaulipas, durante la primera mitad del siglo XX. Tomando en cuenta los factores endógenos y exógenos que incidieron en esta migración, estudio los casos de familias empresariales con participación en los sectores textiles, de bienes raíces y de la industria naviera. A través de fuentes de archivo y una serie de entrevistas con miembros de estas familias, analizo las formas de acumulación de capital de la primera generación de inmigrantes, y sugiero que la relación entre familia y empresa fue un elemento indispensable para la organización, dirección, administración y sucesión de la empresa familiar.

Palabras clave: empresariado libanés; capital; empresa familiar; inmigración; Tamaulipas.

DOI: https://doi.org/10.29105/sillares1.1-2 
Abstract: In this article, I examine the immigration and the formation of the Lebanese business community in Tampico, Tamaulipas, during the first half of the 20th century. Considering the endogenous and exogenous factors involved in this migration, I study the cases of business families in Tampico with participation in the textile, real estate, and shipping industry sectors. Using archival sources and interviews with members of these families, I analyze the forms of capital accumulation of the first generation of immigrants and suggest that the relationship between family and business was crucial in the organization, management, administration, and succession of the family business.

Keywords: lebanese businessmen; capital; family business; immigration; Tamaulipas. 


\section{Introducción}

La formación del empresariado libanés en Tampico es un proceso que es necesario analizar bajo dos ejes estructurales fundamentales: uno relacionado con las formas de acumulación de capital y el otro con la organización empresarial. En el primero, es menester estudiar cómo los libaneses utilizaron un capital social basado en elementos identitarios de su cultura, como el origen común, el idioma y la religión, para transformarlo en capital económico como fuerza de trabajo con el objetivo de acrecentar sus negocios. En el segundo, el análisis debe centrarse en cómo la estructura familiar patrilineal y patrilocal, así como los valores, marcaron la división del trabajo entre los integrantes de ambos géneros; los roles que desempeñaron en el hogar tanto hombres como mujeres fueron trasladados a la empresa familiar, en donde la organización, dirección y sucesión estuvieron dotadas de elementos de carácter patrilineal, con el objetivo de preservar la empresa y el patrimonio por generaciones, dándole suma importancia al apellido paterno.

De esta manera, el objetivo general del presente trabajo es estudiar las formas de acumulación de capital y la relación entre 
familia y empresa como dos elementos indisolubles en la formación del empresariado libanés en Tampico durante la primera mitad del siglo XX. No obstante, también es interesante sumarse al análisis de la migración, explicando los factores endógenos y exógenos que incidieron en la llegada de personas de origen libanés a Tamaulipas, para entender el inicio de la organización social y de trabajo de estos inmigrantes en el país receptor, su manera de ganarse la vida a través de las primeras formas de comercio como buhoneros, su ética enfocada en el trabajo constante, el ahorro y el bajo consumo, como fórmulas para la acumulación y adquisición de un tipo de movilidad social ascendente pasando del comercio informal como vendedores ambulantes al formal con el establecimiento, primero de tiendas, almacenes y posteriormente de fábricas en el ramo de la industria textil, bienes y raíces, así como en la industria naviera.

Con respecto a la estructura del texto, este se comprende de cuatro apartados. En el primero no sólo se indaga sobre los factores que impulsaron la migración, sino también se hace un análisis cuantitativo sobre el número de inmigrantes que llegaron al estado de Tamaulipas entre 1900 y 1930, así como también un análisis sobre el perfil del inmigrante libanés. En el segundo apartado, se explica el inicio de la acumulación de capital a través 
del éxito obtenido en el comercio ambulante, gracias a la implementación de un innovador sistema de ventas; el crédito por abonos, que incorporó a un sector de la sociedad nunca antes tocado; el del campesino pobre y obrero del campo y la ciudad, como sustitución a la tienda de raya en el periodo de la posrevolución. En el tercer apartado, se indaga sobre el modelo de empresa familiar libanés, estrechamente relacionado con la estructura de la familia extensa, en donde la dirección, administración y sucesión atienden a patrones patrilocales. Y, por último, se identifican a partir de la década de 1930, los casos de empresas familiares libanesas y su importancia en el sector textil, bienes raíces e industria naviera en Tampico.

\section{Inmigración y perfil de los primeros inmigrantes libaneses}

El fenómeno migratorio libanés hacia México comenzó a finales del siglo XIX, concretamente a partir de 1878. Es en esta fecha cuando la revista Emir, realizada por la comunidad libanesa en 1938, y las tarjetas de migración, documentan la llegada de los dos primeros libaneses que se insertaron en el país por el puerto de Veracruz, de nombres Boutrous Rafoul ${ }^{1}$ y Antonio Budib, ${ }^{2}$

${ }^{1}$ Archivo Libanés de la Ciudad de México (en adelante ALCM), Emir, número 20, 1938.

2 Archivo General de la Nación (en adelante AGN), Migración, Líbano, Tarjetas de migración, 1934.

DOI: https://doi.org/10.29105/sillares1.1-2 
para después presenciar la llegada de Santiago Sauma, José María Abad y Pedro Dib en 1882, como se relata en el Directorio Libanés realizado por Salim Abud y Julián Nasr en $1948 .{ }^{3}$ Sin embargo, fue hasta 1887 que encontramos el registro del primer libanés que llegó por el puerto de Tampico de nombre Juan Stfen, ${ }^{4}$ un segundo inmigrante en 1894 registrado como Abraham Hatem, para comenzar a tener mayor presencia libanesa en Tamaulipas durante la primera década del siglo XX.

El lugar de procedencia de estos inmigrantes no correspondía a la actual división política de Medio Oriente. Se trataba de la región del Máshreq, ${ }^{5}$ una zona mediterránea que, durante siglos, hasta 1918, estuvo conquistada y ocupada militarmente por el Imperio otomano. Este territorio era conocido como la Gran Siria y comprendía al actual Líbano, Palestina, Israel, Transjordania y la República Árabe Siria. No obstante,

\footnotetext{
${ }^{3}$ Julián Nasr y Salim Abud, Directorio Libanés: censo general de las colonias libanesa-palestina-siria residentes en la República Mexicana (Talleres Linotipográficos "Casa Velux", 1948).

${ }^{4}$ AGN, Migración, Líbano, Tarjetas de migración, 1938.

${ }^{5}$ Máshreq o Máshrek es la palabra en el idioma español para la acepción árabe Al-Masriq, lugar por donde sale el sol, el Levante, o la parte más oriental del mundo árabe, en oposición al Magreb, la parte poniente del mundo árabe. De esta manera, se podría hablar de una población mashrequi, como lo propone Camila Pastor, The Mexican Mahjar: Transnational Maronites, Jews, and Arabs under the French Mandate (Austin: University of Texas Press), 336.
}

Sillares, vol. 1, núm. 1, 2021

DOI: https://doi.org/10.29105/sillares1.1-2 
aunque Líbano se estableció como país independiente hasta 1943, desde el siglo XIII a. C. los fenicios ya hablaban de la región del Monte Líbano, ${ }^{6}$ caracterizada por sus cedros que eran utilizados para las construcciones marítimas, por lo que en este artículo nos referiremos a Líbano en términos geográficos sin implicar la preexistencia de un país.

Los primeros libaneses que llegaron a México, particularmente a Tamaulipas, emigraron en un contexto de desigualdad, violencia, inseguridad, persecución y pobreza a raíz de la guerra civil que se desencadenó entre musulmanes drusos y cristianos maronitas ${ }^{7}$ en la región del Máshreq, suceso que formó parte de la desintegración del Imperio otomano. Esta migración ocurrió al inicio de manera indirecta, debido a las restricciones de las políticas migratorias establecidas en los Estados Unidos en 1903, con respecto a la entrada de inmigrantes. La causa de estas

\footnotetext{
${ }^{6}$ Muchos de los inmigrantes que llegaron a Tamaulipas se autodenominaban sirio-libaneses o libaneses. Estos apelativos de sirio y libanés hacían referencia al origen geográfico, ya que el territorio del Máshreq (parte oriental del mundo árabe) también era conocido como la Gran Siria, mientras que el de libanés era por la región que desde tiempos fenicios se denominaba Monte Líbano.

${ }^{7}$ Los drusos son un grupo religioso cuya fe es procedente del islam; fue fundado en Egipto a finales del siglo X y se extendió en el Máshreq; por otro lado, la población maronita es cristiana de rito oriental y es reconocida por Roma.
}

Sillares, vol. 1, núm. 1, 2021

DOI: https://doi.org/10.29105/sillares1.1-2 
restricciones fue la epidemia de peste bubónica que se desató desde finales del siglo XIX, situación que obligó al Consejo Superior de Salubridad estadounidense a tomar medidas con el objetivo de revisar la entrada de personas provenientes de Asia y Oriente Medio, aumentando en un $70 \%$ los casos de repatriación. ${ }^{8}$

Por esta razón, y gracias a que en México no había restricciones para la entrada de inmigrantes debido al establecimiento de una política porfirista de puertas abiertas, muchos libaneses decidieron esperar en algún puerto mexicano - como Tampico - el momento oportuno para introducirse a los Estados Unidos, ${ }^{9}$ pues se pensaba que en el país norteamericano existían, además de la tolerancia religiosa, mejores oportunidades

${ }^{8}$ Theresa Alfaro-Velcamp, So far from Allah, so close to Mexico: Middle Eastern immigrants in modern Mexico (Austin, University of Texas Press, 2007), 137.

${ }^{9}$ Existían empresas de viajes que, al conocer las condiciones poco favorables para entrar a los Estados Unidos, ofrecían a los migrantes la posibilidad de buscar otro puerto en algún país en donde no existieran las mismas restricciones para ingresar. Lo hacían con el objetivo de convencer a las personas en Líbano de realizar el largo viaje mediterráneo y trasatlántico. Estas agencias se encargaban de otorgar préstamos para financiar los gastos de transporte, a cambio de hipotecas y altos intereses. De esta manera, no sólo México comenzó a recibir inmigrantes libaneses, sino también Cuba, Brasil, e incluso Argentina. Roberto Marín Guzmán, "Las causas de la emigración libanesa durante el siglo XIX y principios del XX. Un estudio de historia económica y social", Estudios de Asia y África 31, núm. 3 (septiembrediciembre, 1996): 602.

DOI: https://doi.org/10.29105/sillares1.1-2 


\section{Inmigración y formación}

laborales. De esta manera, Tamaulipas fungió — durante la primera década del siglo $\mathrm{XX}$ - como un lugar de paso y de estadía temporal en el tránsito de la migración hacia la nación estadounidense, ya que no era una entidad que mostrara un desarrollo industrial importante, pues la industria petrolera apenas comenzaba, a diferencia de la Ciudad de México o Puebla, que fueron centros urbanos en donde se concentró la mayor cantidad de libaneses debido al desarrollo de las manufacturas como la industria textill, ${ }^{10}$ así como en Yucatán en dónde estos inmigrantes tuvieron una participación muy importante en la industria henequenera. ${ }^{11}$

La población libanesa que arribó a Tampico entre 1900 y 1917, fue identificada como turca por los oficiales aduanales, debido a que sus pasaportes, durante esos años, eran expedidos por las autoridades del Imperio Otomano. No obstante, a partir de

\footnotetext{
${ }^{10}$ Una obra que explica muy bien el desempeño de los libaneses en la industria textil en Puebla es Angelina Alonso Palacios, Los libaneses y la industria textil en Puebla (México: Centro de Investigaciones y Estudios Superiores en Antropología Social, 1983), 181.

${ }^{11}$ Para conocer la labor de los libaneses en la península de Yucatán véase Luis Alfonso Ramírez Carrillo, De cómo los libaneses conquistaron la Península de Yucatán: migración, identidad étnica y cultura empresarial (México: Universidad Nacional Autónoma de México, Centro Peninsular en Humanidades y Ciencias Sociales, 2012), 58.
}

Sillares, vol. 1, núm. 1, 2021

DOI: https://doi.org/10.29105/sillares1.1-2 
1918, cuando finalizó la primera Guerra Mundial y la Sociedad de Naciones formalizó el sistema de mandatos en el que Francia resultó ser protectorado del territorio que, a partir de ese momento, se le otorgó el título de El Gran Líbano, los inmigrantes libaneses dejaron de identificarse como turcos para comenzar a presentar documentos referentes a su lugar de origen. El apelativo turco no sólo incluía a los libaneses, sino a la demás población del Máshreq; es por esta razón que los censos oficiales de 1900 a 1921 no son una fuente confiable para precisar el número de libaneses que llegaron a Tamaulipas a principios del siglo XX, sin embargo, nos proporcionan datos significativos relacionados con el aumento y la disminución de la población turca en la entidad.

Según los censos nacionales, en 1900 existían en el país 949 turcos de los cuales sólo 13 se encontraban en el estado de Tamaulipas. En 1910 el número aumentó a 4,463 en todo el territorio nacional y 90 en el estado norteño. Sin embargo, en 1921 las cifras volvieron a descender danto un total de 836 turcos en toda la república, mientras que en la entidad tamaulipeca se 
contabilizaron sólo 12. ${ }^{12}$ Esta disminución entre 1910 y 1921 se debió, en parte, al estado bélico del país ocurrido durante la revolución mexicana, suceso que repercutió en el declive de un marco legal y de una política migratoria que pudiera mantener los derechos de los inmigrantes, como lo había hecho la política porfirista en los años anteriores a los movimientos armados. ${ }^{13} \mathrm{De}$ esta manera, dada la situación del país, muchos turcos decidieron emigrar de México, estableciéndose la mayoría en los Estados Unidos con el objetivo de obtener una mejor calidad de vida.

${ }^{12}$ Censo general de la República Mexicana verificado el 28 de octubre de 1900, conforme a las instrucciones de la Dirección General de Estadística a cargo del Dr. Antonio Peñafiel (México: Secretaría de Fomento, 1901); Tercer censo de población de los Estados Unidos Mexicanos, verificado el 27 de octubre de 1910 (México: Secretaría de Hacienda, Departamento de Fomento, 1918); México. Departamento de la Estadística Nacional, Censo general de habitantes: 30 de noviembre de 1921 (México: Talleres Gráficos de la Nación, 1925).

${ }^{13}$ La Ley de Extranjería y Naturalización de 1886 estipulaba que "los inmigrantes de toda clase, podían naturalizarse [...] quedando equiparados con todos sus derechos y obligaciones con los mexicanos [...] transcurridos seis meses y cuando el extranjero hubiera cumplido dos años de residencia en la República podría pedir al Gobierno federal que le concediera su certificado de naturalización" (art. 13). Se incluyeron, además, exenciones de impuestos, así como transporte y agua gratuitos con el propósito de atraer extranjeros interesados en invertir sus capitales y contribuir al anhelado y reiteradamente mencionado "progreso de la nación". El gobierno apostaba a la inversión extranjera con el objetivo de impulsar la industria, el comercio y la banca en México. Moisés González Navarro, Los extranjeros en México y los mexicanos en el extranjero 1821-1970. Vol 2 (México: El Colegio de México, 1994), 508.

Sillares, vol. 1, núm. 1, 2021

DOI: https://doi.org/10.29105/sillares1.1-2 
Según registros de las aduanas, entre 1910 y 1921 salieron del país por Nuevo Laredo, 30 turcos, ${ }^{14}$ sin embargo, el otro margen numérico puede deberse a que muchos se internaron en la nación norteamericana de manera irregular. Además, durante esos años no se registraron entradas de turcos por el puerto de Tampico, a diferencia del periodo de 1900 a 1909 que se contabilizaron 107 entradas, esto fue debió, no sólo por el conflicto bélico que ocurría en el país, sino también por la política migratoria turca que intentó prohibir la salida de la población a partir de 1909. La principal razón fue la fuerte emigración que estaba causando el despoblamiento de las ciudades en Medio Oriente, la cual estaba dirigida a Europa, Estados Unidos y, en menor medida, a México, Cuba, Brasil y Argentina.

No obstante, una de las fuentes más importantes con las que podemos identificar a la población de origen libanés que entró al país en el periodo de 1900 a 1921, son las tarjetas de migración en su forma F14, expedidas entre 1926 y 1950 por la Secretaria de Relaciones Exteriores (SRE). Estas tarjetas se crearon con la finalidad de tener un mejor control y registro de la

${ }^{14}$ AGN, Aduanas Marítimas y Fronterizas, Tamaulipas, 1910-1921, exp. 334894, Informes aduanales. 
población extranjera en México. Durante el período presidencial de Plutarco Elías Calles se implementó una ley migratoria donde se estableció que las F14 funcionarían como el principal documento de identificación oficial. ${ }^{15}$ Asimismo, en su artículo 32 , la nueva ley anunció que quienes acudieran al registro se les otorgaría una carta de naturalización con la que podrían traer al país a sus padres, hijos, conyugues, e incluso a sus hermanos menores, razón por la que muchos libaneses decidieron registrarse y naturalizarse como mexicanos. ${ }^{16}$

Este tipo de tarjetas migratorias de identidad, contienen datos específicos del inmigrante como su constitución física, edad, nacionalidad, estado civil, idioma, religión, ocupación, fecha de llegada y de registro, lugar de nacimiento, de entrada y de residencia, nombre y domicilio en el país, además de contar con una referencia, así como con la firma del portador y la firma del funcionario de migración junto con el sello de la dependencia. Es menester apuntar que como el registro de esas tarjetas se llevó

\footnotetext{
${ }^{15}$ Víctor Hugo Morales Meléndez y Luis Ricardo López Figueroa, "La política de inmigración de México. Interés nacional e imagen internacional", Foro Internacional XXXIX-1, núm. 155 (enero-marzo, 1999): 71.

${ }^{16}$ González, Los extranjeros en México y los mexicanos en el extranjero 1821 1970. Vol. 2, 19.
}

Sillares, vol. 1, núm. 1, 2021

DOI: https://doi.org/10.29105/sillares1.1-2 
a cabo a partir de 1926, no podemos contar con los datos de los libaneses fallecidos antes de esa fecha, tampoco de aquellos que decidieron emigrar para dirigirse a Estados Unidos o algún otro país. A pesar de estas limitantes, las tarjetas nos proporcionan información valiosa para conocer el número de inmigrantes, al menos registrados, que llegaron a México, en especial a Tamaulipas, a principios del siglo XX ya que, a través de las declaraciones de los inmigrantes sobre la fecha, el lugar de entrada al país y el lugar de nacimiento, es posible realizar una cuantificación del número de libaneses que llegaron a Tampico entre 1900 y 1921. Según las tarjetas, en el periodo que va de 1900 a 1909 entraron al país por Tamaulipas 115 libaneses, para después disminuir el número a 27 inmigrantes entre 1910 y 1921, dando un total de 142 entradas de personas de origen libanés. ${ }^{17}$

Con la comparación de las fuentes, observamos que el número de entradas que nos proporcionan las tarjetas de migración, es mayor al que nos brindan los informes aduanales, a pesar de que en estos últimos sólo existen registros con la denominación de turco. Además, una variación interesante es que en los documentos de las aduanas no hay registros de llegadas

${ }^{17}$ AGN, Migración, Líbano, Tarjetas de migración, 1926-1950.

Sillares, vol. 1, núm. 1, 2021 84

DOI: https://doi.org/10.29105/sillares1.1-2 


\section{Inmigración y formación}

entre 1910 y 1921, mientras que en las tarjetas aparecen 27entradas en los mismos años. ${ }^{18}$ Para explicar esta diferencia, es preciso tener en consideración que a pesar de que las autoridades otomanas dejaron de emitir pasaportes en 1909, la migración no se frenó totalmente, lo que indica que existió un porcentaje, aunque bajo, de la población libanesa que entró al país mexicano, de manera irregular, por el puerto de Tampico.

Asimismo, a través de las tarjetas de migración podemos comprobar que el $75 \%$ de la población que entró por Tamaulipas durante las primeras dos décadas del siglo $\mathrm{XX}$, procedente del Máshreq y con pasaportes turcos, era de origen libanés de las ciudades de Biblos, Djezzin, Deir El Kamar, Zahle, Beirut, Duma, Batrun, Akkar, Karaun, Bekaa y Kesruan. Otro 15\% de los migrantes eran sirio-libaneses; $5 \%$ se declararon sirios que provenían de la ciudad de Damasco; mientras que el resto se registraron como palestinos nacidos en Bethlehem. Asimismo, el 95\% eran cristianos maronitas, es decir, católicos de rito oriental. ${ }^{19}$ Otro dato interesante es que los inmigrantes fueron un $85 \%$ hombres, en su mayoría casados, con edades entre los 15 y

${ }^{18}$ AGN, Migración, Líbano, Tarjetas de migración, 1926-1950.

${ }^{19}$ AGN, Migración, Líbano, Tarjetas de migración, 1926-1950.

Sillares, vol. 1, núm. 1, 2021

DOI: https://doi.org/10.29105/sillares1.1-2 
los 40 años y el resto mujeres entre los 12 y 18; ambos sexos declararon dedicarse al comercio, particularmente de telas, ropa, mercería y en algunos casos de zapatos.

Es preciso señalar que, durante las dos primeras décadas del siglo XX, el estado de Tamaulipas fue sede de una inmigración indirecta, de tránsito y de carácter individual. Según relatos de la misma comunidad libanesa, que aparecen en la revista Emir, los primeros migrantes viajaron a occidente con la intención de encontrar una mejor calidad de vida, para una vez instalados, llevar consigo a sus conyugues e hijos. ${ }^{20}$ Sin embargo, esta migración de carácter familiar —ocurrida incluso desde finales del siglo XIX en otras entidades del país como en Veracruz, Puebla, México y Yucatán- no se presentó en Tamaulipas hasta principios de la década de 1920, cuando el crecimiento de la industria petrolera ya había dinamizado la economía del sur tamaulipeco.

Durante la primera Guerra Mundial, México se convirtió en el segundo exportador de petróleo a nivel mundial, siendo Tampico el principal centro refinador de todo el territorio nacional. De esta manera, la industria petrolera actuó como una

${ }^{20}$ ALCM, Emir, número 26, 1945.

Sillares, vol. 1, núm. 1, 2021 86

DOI: https://doi.org/10.29105/sillares1.1-2 
fuerza de atracción que ocasionó el desplazamiento de extranjeros —incluidos los libaneses - y nacionales de otras partes del país como Veracruz, San Luis Potosí y Guanajuato, que llegaron a la ciudad portuaria con el objetivo de invertir sus capitales o conseguir empleo. ${ }^{21}$ Este fenómeno demográfico estimuló la demanda de bienes y servicios; razón por la que Tampico recibió inyección de capital directo de origen español, francés, inglés y estadounidense al que más tarde se sumarían los libaneses. De esta manera, se establecieron nuevas compañías mercantiles, financieras, de bienes raíces y de servicios, ocupadas en cubrir la demanda de máquinas y refacciones petroleras, así como de vivienda, edificios, terrenos urbanos y rurales, telefonía, electricidad, drenaje, transporte, salud, educación, seguridad, alimentación y turismo. ${ }^{22}$

De esta manera, el dinamismo comercial que se suscitó en la región petrolera del sur tamaulipeco, principalmente en Tampico, es un factor fundamental que explica la continua llegada de población de origen libanés durante la década de 1920.

${ }^{21}$ Roberto Hernández Elizondo, Empresarios extranjeros, comercio y petróleo en Tampico y la Huasteca (1890-1930) (México: Universidad Autónoma de Tamaulipas, Plaza y Valdés S.A. de C.V., 2006), 87-88.

${ }^{22}$ Hernández Elizondo, 103.

Sillares, vol. 1, núm. 1, 2021

DOI: https://doi.org/10.29105/sillares1.1-2 
Según las tarjetas de migración entre 1921 y 1930 entraron al país 7,096 libaneses de los cuales 783 ingresaron por Tamaulipas; la mayoría lo hizo por el puerto de Tampico en donde se registraron 508 entradas. No obstante, un dato interesante es que durante ese período aparece la aduana de Nuevo Laredo como lugar de entrada con 278 registros, así como la de Reynosa con $5,{ }^{23}$ lo que significa que durante la década de 1920 hubo inmigración libanesa proveniente de los Estados Unidos.

Además de la dinámica comercial en el sur de Tamaulipas, otro factor que explica la llegada de personas de origen libanés del país norteamericano, entre 1921 y 1930, es el establecimiento, en 1921, de la Quota Law of may 19, como parte de las reformas a la política migratoria estadounidense de 1917. Esta ley limitó a un 3\% la entrada de extranjeros provenientes de Asia, Medio Oriente y Europa, con respecto al total de la población de esa nacionalidad registrada en el censo de 1910. Asimismo, se exigió que los inmigrantes mayores a 16 años supieran leer y escribir,

${ }^{23}$ AGN, Migración, Líbano, Tarjetas de migración, 1926-1950.

Sillares, vol. 1, núm. 1, 2021 88

DOI: https://doi.org/10.29105/sillares1.1-2 


\section{Inmigración y formación}

así como el pago de una cuota de 8 dólares. ${ }^{24}$ Esta situación frenó la migración directa de libaneses hacia los Estados Unidos y disminuyó las probabilidades de que los inmigrantes allí establecidos pudieran traer consigo a sus familias. Por esta razón muchos decidieron trasladarse a Tamaulipas en donde existían mayores oportunidades para ingresar a sus conyugues e hijos, así como de llevar una mejor calidad de vida, aprovechando la dinámica comercial que se vivía en el sur del estado.

La gran mayoría de la población libanesa en las ciudades Tamaulipecas, en especial en Tampico, que era en donde comenzó a establecerse una colonia más numerosa, se concentraba en el centro de la ciudad, en las calles con mayor flujo de personas y en donde se ubicaban la mayor cantidad de negocios como la calle del comercio, hoy en día Salvador Díaz Mirón, la calle aduana, la calle Muelle, la avenida Colón, la calle Rivera, la avenida Francisco I. Madero, así como la calle del bajo mercado hoy en día Héroe de Nacozari, avenidas que se encontraban entre la Plaza de la Libertad y la Plaza de Armas.

${ }^{24}$ Elisa Ortega Velázquez, "La consolidación histórica de la migración irregular en Estados Unidos: leyes y políticas migratorias restrictivas, ineficaces y demagógicas", Norteamérica 12, núm. 1 (enero-junio 2017): 197231.

Sillares, vol. 1, núm. 1, 2021

DOI: https://doi.org/10.29105/sillares1.1-2 
Asimismo, era una zona muy cercana al puerto y a la estación del ferrocarril (un recorrido a pie de entre 5 y 10 minutos), ya que la ciudad de Tampico creció a orillas del río Pánuco en su desembocadura con el Golfo de México.

La ciudad de Tampico se encuentra aproximadamente a 10 kilómetros de la costa del golfo por lo que, basándonos en el mapa 1, los barcos entraban por la parte nororiental hacia el sur siguiendo la ruta fluvial del río Pánuco hasta llegar al puerto. La ciudad fue creciendo de sur a norte hasta topar con la Laguna del Carpintero, para después continuar su crecimiento hacía ambos extremos. En la década de 1920 la ciudad portuaria mostró un importante crecimiento demográfico y urbano, pasando de 23,450 habitantes en 1921 a 70,183 en $1930,{ }^{25}$ lo equivalente a un crecimiento del $300 \%$ de la población. No obstante, los libaneses que llegaron a Tampico durante los primeros años de la década de 1920, lograron instalarse muy cerca del puerto, al traer después a sus familiares, amigos y conocidos de los mismos pueblos en Líbano, la comunidad fue creciendo principalmente en el centro de la ciudad, lo que en el mapa 1 está señalado en color azul.

${ }^{25}$ Quinto censo de población, 15 de mayo de 1930. Vol. VII, Tomo XXVII: Estado de Tamaulipas (México: Secretaría de la Economía Nacional, 1933).

Sillares, vol. 1, núm. 1, 2021

DOI: https://doi.org/10.29105/sillares1.1-2 


\section{Inmigración y formación}

Es preciso anotar que durante la década de 1920 hubo casos de libaneses que llegaron con suficiente capital para invertir en Tampico, como fue el caso de la familia Appedole, de la cual hablaremos más adelante. Sin embargo, la oleada migratoria de libaneses a Tamaulipas, a partir de 1921, estuvo caracterizada por la llegada de inmigrantes pobres que habían hipotecado sus casas o vendido sus tierras en Líbano para costearse el viaje trasatlántico. ${ }^{26}$ Muchos de ellos llegaron prácticamente sin dinero, algunos lo habían gastado intentado establecerse en los Estados Unidos. Eran en su mayoría analfabetas, de pocos estudios, que se habían dedicado en su tierra natal al comercio y a la agricultura, así como a algunos otros oficios como a la carpintería, herrería o albañilería. ${ }^{27}$

\section{Los precursores del sistema de ventas a crédito por abonos en} Tamaulipas

Los libaneses decidieron dedicarse al comercio al menudeo de la forma ambulante, ${ }^{28}$ que no requería dominio del idioma español

${ }^{26}$ Roberto Marín Guzmán, "Las causas de la emigración libanesa durante el siglo XIX y principios del XX. Un estudio de historia económica y social", Estudios de Asia y África 31, núm. 3 (septiembre-diciembre, 1996): 602.

${ }^{27}$ ALCM, Emir, número 26, 1945.

${ }^{28}$ Muchos autores que se han dedicado al estudio de los libaneses en otras regiones de México, como en Yucatán, Veracruz, Tabasco, Puebla o la ciudad

Sillares, vol. 1, núm. 1, 2021

DOI: https://doi.org/10.29105/sillares1.1-2 
y en donde podían iniciar con un capital pequeño. Implementaron un sistema de ventas, el crédito en abonos, que era una actividad pionera, innovadora y nada practicada hasta entonces, salvo por los judíos en Sinaloa. ${ }^{29}$ La opción de brindar pagos diferidos y

de México, coinciden en que la principal actividad económica en donde se desempeñaron estos inmigrantes fue el comercio informal a través de la forma ambulante. De esta manera, es preciso revisar los trabajos de Rebeca Inclán Rubio, "Inmigración libanesa en la Cd. de Puebla 1890-1930: proceso de aculturación" (Tesis de licenciatura, Universidad Nacional Autónoma de México, 1978); Alonso Palacios, Los libaneses y la industria textil en Puebla; Martha Díaz de Kuri y Lourdes Macluf, De Líbano a México: crónica de un pueblo emigrante (México: Talleres de Gráfica, Creatividad y Diseño, 1995); Carlos Martínez Assad, "Los libaneses inmigrantes y sus lazos culturales desde México", Dimensión Antropológica 15, vol. 44 (septiembre-diciembre, 2008): 133-155; Claudia Dávila Valdés, "Socio-Economic Trajectory and Geographical Mobility of Lebanese and Koreans. From Motul to Mérida", Migraciones Internacionales 8, núm. 2 (julio-diciembre 2015): 103-131; Raymundo Vázquez Soberano, "Los sirio-libaneses en Tabasco. La conformación de un grupo dominante: 1910-1935" (Tesis de doctorado, Universidad Veracruzana, 2016); Lorenza Petit, "El Mahyar mexicano. Producción literaria y periodística de los inmigrantes árabes y sus descendientes" (Tesis de doctorado, Universidad Autónoma de Madrid, 2017); Oscar Israel Pizaña-Grimaldo, "Del Máshrek hacia México: la formación de la colonia libanesa en Tampico, 1882-1948”, Revista de Filosofía y Cotidianidad 4, núm. 11 (junio 2018): 20-32; y Luis Alfonso Ramírez Carrillo, "Identidad persistente y nepotismo étnico: movilidad social de inmigrantes libaneses en México", Nueva Antropología. Revista de Ciencias Sociales 31, núm. 89 (julio-diciembre 2018): 9-23.

${ }^{29}$ María Eugenia Romero Ibarra, "Del pequeño almacén a los negocios financieros. Tres sucesiones exitosas en una familia empresaria: Grupo Coppel, 1940-2010", en Familias empresariales en México. Sucesión generacional y continuidad en el siglo XX, coord. Araceli Almaraz y Luis Alfonso Ramírez (Tijuana: El Colegio de la Frontera Norte, 2018), 227-254.

Sillares, vol. 1, núm. 1, 2021

DOI: https://doi.org/10.29105/sillares1.1-2 


\section{Inmigración y formación}

con tasas de interés bajas, significó una ventaja sobre los comerciantes locales en relación con clientela y mayores ventas. Procuraban ofrecer plazos de liquidación cortos, para que los compradores adquirieran nuevos productos, además, manejaban "abonos chiquitos" semana con semana — como la gente del pueblo les llamaban- y otorgaban las mercancías sin pago anticipado, porque sabían que a sus compradores les interesaba conseguir los artículos sin tener la necesidad de descapitalizarse.

El éxito que tuvo la venta a crédito y el cobro en abonos radicó en que este sistema incorporó a un nuevo sector de la población que antes no se tocaba, el campesino y el obrero pobre del campo y la ciudad. Significó el acaparamiento de un nuevo mercado, mayor clientela y el aumento de la capacidad de venta. Asimismo, la disminución de las tiendas de raya, con las que se endeudaban los peones y agricultores, dio lugar a la liberación del comercio y a una mayor circulación del dinero, ampliando el mercado interno en todo Tamaulipas, con una población que pese a sus bajos ingresos podía consumir bienes de subsistencia y vestido. Esta coyuntura fue aprovechada por los buhoneros libaneses para sustituir el crédito que otorgaba la tienda de raya de las haciendas por la venta en abonos. ${ }^{30}$

${ }^{30}$ Ramírez, De cómo los libaneses conquistaron la Península de Yucatán: migración, identidad étnica y cultura empresarial, 168.

DOI: https://doi.org/10.29105/sillares1.1-2 
La mercancía de estos buhoneros consistía en objetos de bisutería, artículos para el cabello, hilos y enseres de mercería, imágenes religiosas, telas, ropa confeccionada, incluso zapatos y relojes. No obstante, a través de la socialización con el pueblo pudieron conocer las necesidades de sus clientes e incorporar nuevos productos a petición de sus compradores, como sandalias, sombreros, herramientas para trabajar, colchas, mantelería, sabanas y toallas. ${ }^{31}$ Todo esto lo ponían en cajas, cajones o maletas. No sólo emprendían su recorrido por las ciudades, sino también se internaban en los poblados más cercanos, desplazándose en ferrocarril, en vehículos de muy malas condiciones o a lomo de mula. También visitaban rancherías y caseríos caminando por veredas angostas y peligrosas, como nos cuenta Neder Nader Habib (de 93 años de edad, de ascendencia libanesa, nacido en Tampico y fundador de la empresa de uniformes UNITAM S.A. de C.V en 1956) sobre la labor de su padre como buhonero:

Mi padre Juan [Nader] llegó a Tampico en 1918 para dedicarse al comercio ambulante. Era soltero en aquel entonces y quien le ofreció mercancía para vender fue un comerciante también

\footnotetext{
${ }^{31}$ Nasr y Abud, Directorio Libanés: censo general de las colonias libanesapalestina-siria residentes en la República Mexicana.
} 
de origen libanés de nombre Damián Abad quien había llegado de Veracruz y contaba con una tienda de ropa, telas y mercería en la calle Rivera y Colón llamada "La Universal". Mi padre comenzó a vender hilos, botones, agujas, listones, cordones, telas, ropa y sombreros para los campesinos, primero andaba a pie, después le prestaron una mula para insertarse en las comunidades y en el campo para ir ofreciendo los productos porque tenía que cumplir con un mínimo de venta diaria. Mi papá buscaba clientes y a veces se iba a las parcelas en donde andaban trabajando los campesinos para ofrecerles sombreros". ${ }^{32}$

Para ofrecer estas mercancías, nos cuenta Neder, su padre y los demás buhoneros necesitaron aprender palabras básicas en español, pero lo más importante era conocer los nombres de los productos, para poder ir anunciándolos por las calles, así como familiarizarse con el uso de la moneda mexicana para no equivocarse en los cobros y perjudicar a los clientes evitando hacerse de mala reputación, aunque con el tiempo y el constante diálogo con sus compradores comenzaron a dominar el idioma

\footnotetext{
${ }^{32}$ Entrevista a Neder Nader Habib, 25 de noviembre de 2019. Neder Nader es un empresario de ascendencia libanesa nacido en Tampico, Tamaulipas en 1927 por lo que en la actualidad cuenta con 93 años de edad, se encuentra en perfectas condiciones de salud y fue fundador de la empresa UNITAM S.A de C.V., creada en 1956, en la actualidad es una de las empresas de uniformes más grandes en el país con sucursales en toda la república mexicana. A través de la entrevista, nos brindó información muy valiosa sobre la vida de los buhoneros libaneses, como lo fueron sus padres, en la década de 1920.
}

Sillares, vol. 1, núm. 1, 2021

DOI: https://doi.org/10.29105/sillares1.1-2 
local, sin perder su peculiar acento. ${ }^{33}$ Algunos buhoneros conseguían un ayudante para los largos recorridos, pero en la mayoría de los casos, ellos mismos eran los cargadores y administradores de su mercancía, llevando la contabilidad en una libreta pequeña que cupiera en sus bolsillos del pantalón en donde marcaban la gestión de deuda, abonos e itinerarios de la semana.

Quienes no sabían escribir copiaban los números de las casas de sus compradores o hacían una serie de rayas y círculos para contar las cosas que vendían. Con el propósito de acumular capital, hacerse de un local, establecer su propia tienda y traer a su familia de Líbano, vivían bajo una ética de bajo consumo y mucho ahorro. ${ }^{34}$ Gastaban sólo en lo indispensable para subsistir, como en alquiler, despensa y en ocasiones ropa; el calzado lo cambiaban hasta que se les rompía. Una vez que los inmigrantes se lograban establecer en un comercio fijo, de manera formal, logrando tener un sustento económico, se concentraban en traer primordialmente a sus conyugues e hijos y en menor medida a sus padres $^{35}$ para, después, traer también a hermanos, cuñados,

${ }^{33}$ Entrevista a Neder Nader Habib, 25 de noviembre de 2019.

${ }^{34}$ Entrevista a Neder Nader Habib, 25 de noviembre de 2019.

${ }^{35}$ El porcentaje de población inmigrante adulta (mayores de 40 años) fue muy bajo, del 3\%. Por lo regular decidían quedarse en Líbano porque no tenían

Sillares, vol. 1, núm. 1, 2021

DOI: https://doi.org/10.29105/sillares1.1-2 


\section{Inmigración y formación}

primos y amigos muy cercanos o recomendados de sus parientes dando paso a una migración escalonada o de tipo comunitario, que tomó fuerza a finales de la década de 1920 y durante la siguiente.

Los ya establecidos ofrecieron empleo a sus parientes y amigos, ya fuera como repartidores de sus mercancías, es decir, como buhoneros o se les otorgaba crédito, el cual consistía en proporcionar una cantidad suficiente de artículos a un precio muy por dejo de lo establecido en el mercado, con el propósito de que surtieran su propia tienda. Asimismo, se les brindaba asistencia comunitaria como alojamiento, comida, ropa, herramientas y todo lo necesario para facilitarles el periodo de adaptación inicial. ${ }^{36}$ La oferta de trabajo y el apoyo ofrecido por sus connacionales en el país receptor, significaron un seguro de vida para la población migrante, ya que muchos viajaban prácticamente contratados. De esta manera, una vez que

interés en pasar el resto de su vida en otro país con elementos culturales diferentes a los de su lugar de origen ya que, bien o mal, la mayor parte de su vida estaba realizada. Se interesaban más en apoyar a sus hijos para que salieran a buscar un mejor futuro, aunque estuvieran conscientes sobre la posibilidad de no volverlos a ver. Entrevista a Carlos Martínez Assad, sociólogo dedicado al estudio de la herencia cultural de los libaneses en México, 12 de septiembre de 2019.

${ }^{36}$ ALCM, Emir, número 26, 1945.

Sillares, vol. 1, núm. 1, 2021

DOI: https://doi.org/10.29105/sillares1.1-2 
desembarcaban en el puerto tampiqueño, no tardaban más de tres días para ser asistidos por parientes, conocidos o amigos. Algunos, en un par de días ya se encontraban trabajando como buhoneros, vendiendo por las calles gran variedad de productos en abonos, gastando lo mínimo y ahorrando lo máximo posible.

\section{El modelo de empresa familiar}

Si anteriormente solían viajar solos hacia occidente para encontrar trabajo, ahorrar dinero y poder reunirse con la familia, durante la década de 1920 los libaneses pudieron viajar a Tamaulipas acompañados de familias enteras o incluso de amigos y conocidos de los mismos pueblos de origen. La oferta de trabajo generada por el crecimiento de los negocios de los primeros inmigrantes hacía posible este fenómeno, lo que significó vencer la incertidumbre de la migración que había permeado durante las décadas anteriores. Fue así como terminó el período de las migraciones individuales para dar paso a la migración comunitaria. De esta manera, desde el momento en que se arribaba en el puerto de Tampico, cada uno de los integrantes de la familia desempeñaba un rol especifico, según su división del trabajo. 


\section{Inmigración y formación}

Eran más los hombres que se encargaban de salir a las calles a vender y ofrecer la mercancía, con el objetivo de llevar el sustento económico a su esposa e hijos, mientras que las mujeres se quedaban en la casa desempeñando las labores del hogar, como preparando la comida y haciendo el aseo. ${ }^{37}$ Sin embargo, hubo casos de mujeres viudas que llegaron a Tampico con sus hijos e hijas y que se dedicaron a trabajar como buhoneras para salir adelante como sucedió con Salime Abi Rachid ${ }^{38}$ quien, tras la muerte de su esposo en 1921, emigró a Tampico con 29 años de edad, procedente de Jazzín, acompañada de sus dos hijos, Antonio y Faustino, siendo recibida por sus dos hermanos, César y Salomón quienes le brindaron alojamiento. ${ }^{39}$

Por lo regular las mujeres viudas no emigraron solas con sus hijos, sino que venían acompañadas de sus hermanos - como fue el caso de Salime-, lo que posibilitaba acortar el período de trabajo en la calle porque gracias a los ahorros de todos era más

\footnotetext{
${ }^{37}$ Entrevista a Max Appedole, nieto de José Appedole, fundador de Astilleros de Tampico S.A., 5 de junio de 2020; entrevista a Neder Nader Habib, 25 de noviembre de 2019; y entrevista a Carlos Martínez Assad, sociólogo dedicado al estudio de la herencia cultural de los libaneses en México, 12 de septiembre de 2019.

${ }^{38}$ Tarjetas de migración, 1926-1950, AGN, Migración, Líbano.

${ }^{39}$ Entrevista a Teresa Rachid, descendiente de la tercera generación de la familia Abi, 15 de mayo de 2019.
}

Sillares, vol. 1, núm. 1, 2021

DOI: https://doi.org/10.29105/sillares1.1-2 
fácil adquirir una casa para vivir juntos y acondicionar su propio local de venta. Una vez que lograban hacerse de su patrimonio e instalar su propia tienda, continuaban ahorrando para que cada uno de los hermanos y hermanas tuviera su propio negocio, siendo el hermano mayor el que se quedaba con la primera tienda. Se procuraba incorporar diversos giros; si se iniciaba con una mercería, al paso del tiempo se ponía una zapatería o una tienda de ropa, telas, artículos religiosos, entre otras cosas, ya que por lo regular los locales se encontraban juntos debido a que todos vivían en una misma casa y mientras continuaba creciendo la familia, procuraban comprar las propiedades aledañas. ${ }^{40}$

Según fue creciendo la parentela, llevaron a cabo un modelo de familia extensa en donde vivían por lo regular tres generaciones o en algunos casos más, según la longevidad de los abuelos. En este tipo de familia, estaban los inmigrantes fundadores, sus hijos varones con sus esposas, su descendencia, que eran nietos de los fundadores, y en algunos casos los hijos de los nietos. Era patrilocal, pues las mujeres cuando se casaban se

\footnotetext{
${ }^{40}$ Entrevista a Neder Nader Habib, 25 de noviembre de 2019; y entrevista a Cesar Askille, descendiente de la tercera generación de la familia Askille, 14 de octubre de 2019.
} 
iban a vivir con las familias del esposo, a excepción de los casos en que las fundadoras fueron mujeres. ${ }^{41}$ No obstante, y con respecto a la herencia de los bienes familiares, ésta era patrilineal ya que la empresa se heredaba a los hombres, principalmente al primogénito, pues a través de los varones se garantizaba la permanencia de los bienes y del apellido. Sin embargo, este traspaso no se realizaba sino hasta la muerte del fundador, con el objetivo de no arriesgar este tipo de patrimonio ya que el hijo, ya fuera por falta de madurez, de compromiso o de tiempo, por dedicación en la escuela u otras actividades, podría llevar a cabo una mala administración y en el peor de los casos la venta o traspaso de la empresa familiar. ${ }^{42}$

\footnotetext{
${ }^{41}$ Muchos investigadores coinciden con el modelo de familia extensa que adoptaron los libaneses durante las primeras tres generaciones en México. Véase Inclán Rubio, "Inmigración libanesa en la Cd. de Puebla 1890-1930: proceso de aculturación"; Alonso Palacios, Los libaneses y la industria textil en Puebla; Díaz de Kuri y Macluf, De Líbano a México: crónica de un pueblo emigrante; Martínez Assad, "Los libaneses inmigrantes y sus lazos culturales desde México"; Vázquez Soberano, "Los sirio-libaneses en Tabasco. La conformación de un grupo dominante: 1910-1935"; Petit, "El Mahyar mexicano. Producción literaria y periodística de los inmigrantes árabes y sus descendientes"; y Ramírez Carrillo, "Identidad persistente y nepotismo étnico: movilidad social de inmigrantes libaneses en México".

${ }^{42}$ Entrevista a Max Appedole, 5 de junio de 2020; entrevista a Neder Nader Habib, 25 de noviembre de 2019; y entrevista a Carlos Martínez Assad, 12 de septiembre de 2019.
}

Sillares, vol. 1, núm. 1, 2021

DOI: https://doi.org/10.29105/sillares1.1-2 
En los pocos casos en que las mujeres fueron las fundadoras, de igual manera se procuraba heredar al varón. Para el momento en que el hijo mayor heredaba la empresa, ya habían pasado por lo regular tres generaciones. Durante ese tiempo, el abuelo fundador se encargaba de insertar en las redes clientelares y de negocios a sus hijos y a sus nietos, dotándolos de experiencia en la administración de la mercancía y el dinero, además de enseñar una ética de trabajo que debía prevalecer por generaciones en donde estaban involucrados ciertos principios como la honestidad, la humildad, la lealtad y la perseverancia, además del ahorro. Era una visión de superación y crecimiento a largo plazo con el objetivo de garantizar la preservación de la empresa. No obstante, las mujeres poco participaban en la vida empresarial de la familia, al menos hasta la segunda generación, porque la apuesta en la permanencia y continuidad de la empresa estaba centrada en la figura del varón, pues las mujeres al casarse recibían los bienes de su esposo.

De esta manera, las hijas y nietas no sólo se mantenían distantes, sino que también se les confiaba poca información sobre los negocios de la familia. Incluso, cuando se requería de personal para echar andar un nuevo establecimiento, no se 
involucraba a las mujeres, se prefería contratar empleados, que fueran hombres de confianza. Esto no significaba que las mujeres estuvieran desprotegidas o que no heredaran ningún tipo de bien material, pues heredaban propiedades como casas, así como capitales ${ }^{43}$ pero se tenía la idea de que la administración de la empresa tenía que estar en manos de los hombres, entre otras cosas porque el apellido era muy importante y eso permitía que prevaleciera por generaciones. No se heredaba la propiedad de una empresa a una mujer porque en la siguiente generación se imponía el apellido del esposo y, por ende, se perdía la sucesión generacional patrilineal.

De esta manera, la unidad y la continuidad de la familia eran los elementos primordiales de estos inmigrantes. Una manera de asegurar el bienestar familiar era a través de la preservación de la empresa; de ahí nació la ideología empresarial de los libaneses, pues no sólo importaba acumular capital para enriquecerse, sino para garantizar la permanencia, estabilidad y bienestar de las siguientes generaciones. Se trabajaba para construir un patrimonio del que pudieran disfrutar los hijos y

43 Testamentos, Archivos particulares de las familias Nader, Appedole, Askille, Abad, Chemaly, Schekaiban.

Sillares, vol. 1, núm. 1, 2021

DOI: https://doi.org/10.29105/sillares1.1-2 
nietos, y era también responsabilidad de éstos preservarlo y heredarlo a sus descendientes. Por esta razón, se valoraba lo construido con esfuerzo de muchos años e incluso de varias generaciones. En este sentido, la preservación de la empresa garantizaba, en gran medida, la continuidad de la propia familia. No se trabaja y se aumenta el capital sólo por la razón de hacer dinero, se trabaja para hacer familia. ${ }^{44}$ Es por esta razón que familia y empresa fueron dos elementos indisolubles en la vida intergeneracional de los libaneses.

\section{El empresariado libanés}

Es difícil establecer un período de tiempo exacto que marque la pauta del comercio informal (ambulante) al formal (tiendas, almacenes, fábricas y demás empresas) en Tamaulipas. Sin embargo, es posible identificar que durante la década de 1930 aparecen en Tampico muchos comercios en los que están involucrados los libaneses y en los que destacaban las tiendas de ropa y telas como "El Mayorista"45 de Amín Askille, ubicada en

${ }^{44}$ Entrevista a Max Appedole, 5 de junio de 2020; entrevista a Neder Nader Habib, 25 de noviembre de 2019.

${ }^{45}$ Archivo Histórico de Tampico (en adelante AHT), Artículos de folletería, caja 18, exp. 104, Folleto de publicidad del almacén de ropa "El Mayorista", 1937.

Sillares, vol. 1, núm. 1, 2021

DOI: https://doi.org/10.29105/sillares1.1-2 
la calle muelle, "El Colibrí" de Domingo Mennah, en avenida Colón, "La Vencedora S. A.” de Juan Nader, en calle Olmos, "La Universal" de Damian Abad, en Rivera y Colón, "Almacenes Celia" de Salvador Musa, en calle Rivera, "La Colorada" de Santos Nasta, en avenida Francisco I. Madero, los almacenes "Miguel Saiman y Cía." de Miguel Saimán en calle muelle, “Almacenes La Estrella", en la avenida Hidalgo, de los hermanos Jorge Elías, José Elías y Juan Chemaly, los "Almacenes El Porvenir" de Tovias Salúm, en calle Rivera y "La Esperanza S. A." de David Schekaiban, ubicada en calle Olmos. ${ }^{46}$

Asimismo, existían mercerías como "La Libertad" de José Jalil, ubicada en Olmos y Madero, la "Mercería Kawache" de Malek Kawache, en Muelle y Madero, "La oriental" de Enrique Manzur, en la calle Muelle, la "Mercería Jazmín” de los hermanos Nicolás y Eduardo Kuri, en la calle Rivera y Olmos, así como "El Sol" de Daniel Haled en avenida Hidalgo. ${ }^{47}$ Aunque las tiendas de ropa, telas y mercería eran los giros en los que más se

\footnotetext{
46 Archivo General de Notarías del Estado de Tamaulipas (en adelante AGNET), Protocolos notariales de Tampico, 1930-1938, Boletín de la Cámara Nacional de Comercio de Tampico, 1 de octubre de 1938.

47 AGNET, Protocolos notariales de Tampico, 1930-1938, Boletín de la Cámara Nacional de Comercio de Tampico, 1 de octubre de 1938.
}

Sillares, vol. 1, núm. 1, 2021

DOI: https://doi.org/10.29105/sillares1.1-2 
distinguían los libaneses, también encontramos algunos otros comercios relacionados con la venta de calzado como "La zapatería El Cairo" propiedad de Mina Andonié, en avenida Francisco I. Madero, la tienda "Calzado Issa" de Juan Issa, en calle Muelle, así como "Mayoristas de calzado" de Juan Warra. También estaban los negocios relacionados con la maderería o materiales de construcción como "La Continental, S. A." de José Appedole ${ }^{48}$ ubicada en la avenida Carranza y "Materiales La Ceiba S. A.” de Nalf Athié Massad, en calle Aduana.

Algunos otros invirtieron sus capitales en hotelería como Abraham Abisulaiman que construyó su primer hotel "Alta Vista", ubicado en Rivera y Colón, al igual que Nasser Hage quien compró una propiedad de tres plantas en la calle Tamaulipas y Aurora con el objetivo de acondicionarla como un hotel al que llamó "La Villa". Además de los giros anteriores, también se identificaron los negocios relacionados con la venta

${ }^{48} \mathrm{El}$ apellido real de José era Abdalláh, pero regularmente las autoridades mexicanas registraban a los inmigrantes según entendían la pronunciación de sus nombres en árabe, por esta razón Abdalláh se transformó en Appedole. Así, muchos nombres y apellidos se cambiaron: Férez pasó a ser Pérez, Fares se volvió Félix, Butros se convirtió en Pedro y Maryem en María. Zéraoui, Zidane, "Los árabes en México: entre la integración y el arabismo", Revista Estudios, núms. 12-13 (julio-diciembre 1995): 13.

Sillares, vol. 1, núm. 1, 2021

DOI: https://doi.org/10.29105/sillares1.1-2 


\section{Inmigración y formación}

de los alimentos, como los restaurantes "La Laguna" de Jorge Kawache y "El Mundo" de Jorge Fayad en Díaz Mirón. ${ }^{49}$

De estos comerciantes y pequeños empresarios libaneses que prosperaron en sus primeros negocios formales, hubo algunos que se destacaron en la industria textil, naviera y de bienes raíces. Aprovecharon las coyunturas de crisis económicas que se vivieron en México, para hacerse de nuevas propiedades. Cuando ocurrió la Gran Depresión a causa de la caída de la Bolsa de Wall Street en 1929, el peso mexicano sufrió una fuerte devaluación ocasionando que muchas empresas quedaran en quiebra, ${ }^{50}$ algunas de las cuales fueron adquiridas por libaneses que contaban con el capital suficiente para poder comprarlas. Estos extranjeros, muchos ya nacionalizados, no confiaban en la moneda mexicana, por lo que procuraban utilizar el patrón oro, lo cual era también un modo de ahorro que les otorgaba mayor capacidad de liquidez. Este fue el caso de Juan Nader, quien, después de establecer su propia tienda de ropa y telas, compró en

49 AGNET, Protocolos notariales de Tampico, 1930-1938, Boletín de la Cámara Nacional de Comercio de Tampico, 1 de octubre de 1938.

${ }^{50}$ Enrique Cárdenas, La hacienda pública y la política económica, 1929-1958 (México: Fondo de Cultura Económica, 1994), 90.

Sillares, vol. 1, núm. 1, 2021

DOI: https://doi.org/10.29105/sillares1.1-2 
1935 una fábrica textil dedicada a la elaboración de ropa, a la cual también llamó "La Vencedora S. A.". 51

Juan era el accionista mayoritario de la empresa, aunque también eran propietarios sus hermanos, Jorge y Enrique. La fábrica contaba con alrededor de 65 obreros, pero también tenían contratados cargadores, transportistas y personal para el aseo, mientras que los mismos miembros de la familia como sus hijos y sobrinos aprendían de Juan y de sus hermanos actividades relacionadas con la administración y dirección de la empresa, así como a realizar inventarios, llevar a cabo la contabilidad, los itinerarios de entrega y atender los pedidos de sus clientes. La familia Neder se posicionó rápidamente entre los principales proveedores de las tiendas de ropa de la ciudad, muchas de ellas de libaneses; por ejemplo, los almacenes "El Mayorista", propiedad de Amín Jaskille, les compraban 25 pacas de ropa por semana, siendo uno de los principales clientes de los Nader. Asimismo, al paso del tiempo fueron extendiendo su distribución, vendiendo ropa a tiendas de otras localidades como Tuxpan y El Ébano, en Veracruz, Matehuala y la capital potosina, así como en Ciudad Victoria y Ciudad Mante, en el estado de Tamaulipas.

\footnotetext{
${ }^{51}$ AGNET, Protocolos notariales de Tampico, 1930-1938.
} 


\section{Inmigración y formación}

David Schekaiban fue otro empresario libanés que durante la contracción económica pudo adquirir a un precio muy bajo una antigua bodega de granos de unos comerciantes españoles, para instalar su propia fábrica de zapatos, "Fabricantes de Calzado S.A", ${ }^{52}$ la cual estaba ubicada en la calle Cristóbal Colón. Otorgó empleo a muchos libaneses que se insertaron en Tampico a principios de la década 1930, pues muchos empresarios como David aprovecharon la continua migración para utilizar un capital social, basado en elementos identitarios de la cultura libanesa como el origen común, la religión y el idioma, para transformarlos en capital económico como fuerza de trabajo, con el objetivo de acrecentar sus negocios y acumular mayor cantidad de dinero. ${ }^{53}$ La empresa se convirtió en una de las principales proveedoras de calzado no sólo a nivel local sino también

${ }^{52}$ AGNET, Protocolos notariales de Tampico, 1930-1938.

${ }^{53}$ Aunque el interés es acumular capital, se le tenía mayor confianza a un libanés por compartir con éste elementos culturales, sociales y psicológicos comunes, relacionados con lo simbólico, lo vivido, lo histórico, lo íntimo, lo identitario y lo colectivo. Es decir, elementos culturales y sociales comunes que marcaron la unión de la población libanesa y que generan relaciones más estrechas entre la comunidad. La manera de preservar estas relaciones fue a través de ciertos valores como la lealtad, el respeto, la sinceridad y la honradez, que en su conjunto otorgan la confianza. Es por esta razón que se generaron relaciones preferenciales en donde muchos empresarios como David procuraban emplear libaneses.

Sillares, vol. 1, núm. 1, 2021

DOI: https://doi.org/10.29105/sillares1.1-2 


\section{Oscar Pizaña}

regional, distribuyendo sus productos a las zapaterías y tiendas de otros municipios como Ciudad Victoria y Ciudad Mante y a otras entidades como Veracruz y San Luis Potosí.

David y su familia habían comenzado como pequeños comerciantes con el establecimiento de una tienda de ropa y telas en 1926, sin embargo, después de fundar la fábrica de zapatos, se concentraron en el negocio del calzado y comenzaron a abrir nuevas zapaterías, para vender los productos que ellos mismos fabricaban, las cuales quedaron a cargo de sus hijos Salomón, Jacinto y Julián quienes, a su vez, las administraban apoyados de sus familias, ${ }^{54}$ aunque es preciso decir que la empresa creció gracias a las redes clientelares de carácter regional que fueron creando para la venta de su calzado. Una de las razones por las que muchos dueños de negocios preferían adquirir productos al mayoreo de la fábrica de David y no de otros mayoristas locales, fue por la especialización que fueron desarrollando en la elaboración de su calzado, la cual estaba orientada a fabricar zapatos y botas no sólo casuales sino también de trabajo, de una larga durabilidad, razón por la que los Schekaiban se comenzaron

\footnotetext{
${ }^{54}$ Entrevista a Jesús Schekaiban, descendiente de la tercera generación, hijo de Salomón, 4 de marzo de 2019.
}

Sillares, vol. 1, núm. 1, 2021

DOI: https://doi.org/10.29105/sillares1.1-2 


\section{Inmigración y formación}

a apropiar de un mercado en donde estaba involucrado el sector obrero industrial y campesino.

Otro factor que incidió en la acumulación de capital de algunos empresarios libaneses fue el cambio institucional de la propiedad privada ocurrida en 1934, cuando el Estado mexicano, a través de una nueva reforma agraria, decidió expropiar las haciendas y grandes propiedades para crear nuevas unidades de producción de la tierra, dando paso a la creación de los ejidos, situación que generó no sólo el abaratamiento de la propiedad rural, sino indirectamente también de la urbana, ya que muchos hacendados - con el objetivo de recuperar parte de sus capitales - decidieron vender muchas de sus propiedades en las cabeceras de los pueblos y en las ciudades. ${ }^{55}$ Muchos de estos bienes fueron también adquiridos por libaneses como fue el caso de los hermanos Abraham, Pedro y Agustín Abisulaiman Kuri quienes, gracias a la compra de muchas propiedades en los territorios aledaños a Tampico, incluyendo de Veracruz, lograron

55 Jean Phillippe Colin, Christophe Blanchot, Enrique Vázquez y Hermilio Navarro, "Reforma agraria, dinámicas organizativas y prácticas agrarias. El caso de Graciano Sánchez, Tamaulipas, México", coord. Éric Leonard y André Quesnel (México: Centro de Investigaciones y Estudios Superiores de Antropología Social, 2003): 73-106.

Sillares, vol. 1, núm. 1, 2021

DOI: https://doi.org/10.29105/sillares1.1-2 
fundar en 1938 la Compañía Abisulaiman y Cía., ${ }^{56}$ dedicada a la compra y venta de bienes raíces, y donde el accionista mayoritario era Abraham, quien contaba con mayor capital y había logrado traer de Líbano a sus hermanos junto con sus familias.

No obstante, es preciso mencionar que desde inicios de la década de 1920 también hubo inyección directa de capital libanés, como fue caso de José Appedole, quien llegó con su familia después de vender su antigua fábrica de cigarros en Biblos (lugar donde nació) a causa de las requisas que imponía el Imperio otomano durante la Primera Guerra Mundial. Llegó al puerto de Tampico en 1921 y fue hasta 1924 que creó "La Continental S. A." ${ }^{57}$ que además de ser una empresa dedicada a la venta de materiales de construcción y madera, estaba especializada en la fabricación de chalanes, los cuales eran barcos planos de acero que se utilizaban para que los autos cruzaran el río Pánuco y conectaran por carretera la ciudad de Tampico con Veracruz. Appedole era el único capacitado y habilitado para construir en

\footnotetext{
${ }^{56}$ AGNET, Protocolos notariales de Tampico, 1930-1938.

${ }^{57}$ Nasr y Abud, Directorio Libanés: censo general de las colonias libanesapalestina-siria residentes en la República Mexicana.
}

Sillares, vol. 1, núm. 1, 2021

DOI: https://doi.org/10.29105/sillares1.1-2 


\section{Inmigración y formación}

México este tipo de embarcaciones, así como también era el único con reconocimiento legal para fungir como perito responsable de los planos constructivos, ${ }^{58}$ ya que su empresa era la única de su tipo.

Al no existir otra empresa dedicada a la fabricación de barcos, Appedole ideó la creación de una empresa más grande que "La Continental" para la construcción y reparación de buques de carga, hechos de acero y madera, que sirvieran para transportar grandes toneladas de crudo y maquinaria pesada para las compañías petroleras. De esta manera, fundó en 1938 “Astilleros de Tampico, S. de R. L.," ubicada en la 3ra avenida Isleta, con un capital limitado de 2,500,000 pesos; ésta contó con 100 acciones, de las cuales 94 eran de su propiedad, y el resto de particulares. Fue así como Appedole se convirtió en el fundador y promotor de la industria naviera en Tampico, teniendo tres turnos de trabajadores y funcionando las 24 horas del día.

Este empresario prominente, conoció al presidente Lázaro Cárdenas, desde que éste trabajaba como General en Jefe de la zona militar de Pueblo Viejo, Veracruz. ${ }^{59}$ No obstante, la relación

${ }^{58}$ Entrevista realizada a Max Appedole, 5 de junio de 2020.
${ }^{59}$ Entrevista realizada a Max Appedole, 5 de junio de 2020.

Sillares, vol. 1, núm. 1, 2021

DOI: https://doi.org/10.29105/sillares1.1-2 
de ambos se hizo más estrecha cuando el libanés mostró con su fábrica armadora la habilidad de reconfigurar y rediseñar, trabajando el acero, las piezas indispensables para reestablecer la capacidad de explotación de la industria petrolera mexicana durante el embargo comercial producto de la expropiación petrolera de 1938 hacia las compañías norteamericanas, inglesas y holandesas. ${ }^{60}$ Fue así que gracias a "Astilleros de Tampico", se pudo sustituir la maquinaria extranjera para la excavación y extracción del crudo siendo una labor muy importante para el gobierno nacional. Además, a pesar del cierre comercial con las potencias europeas y norteamericana, México continuó exportando petróleo a Alemania, Italia y Japón, ${ }^{61}$ salvando, de esta manera, los primeros años de la empresa paraestatal mexicana de petróleos.

El petróleo que llegaba a Alemania proveniente de México era procesado en las refinerías de la ciudad de Hamburgo, y la mayor parte del combustible producido era utilizado en la

${ }^{60}$ Entrevista realizada a Max Appedole, 5 de junio de 2020.

${ }^{61}$ Daniela Gleizer, "Las relaciones entre México y el Tercer Reich, 19331941”, Tzintzun. Revista de Estudios Históricos, núm. 64 (julio-diciembre 2016): 223-258.

Sillares, vol. 1, núm. 1, 2021

DOI: https://doi.org/10.29105/sillares1.1-2 


\section{Inmigración y formación}

fuerza aérea, la Luftwaffe. ${ }^{62}$ De esta manera, a pesar del boicot que realizaron los Estados Unidos, Inglaterra y Holanda hacia México, exigiendo a sus aliados que no compraran crudo a Petróleos Mexicanos (PEMEX), el país alcanzó una producción de 38.8 millones de barriles anuales a partir de 1938, atendiendo una fuerte demanda del exterior, mientras que de esa cantidad total producida se exportaba alrededor del $70 \%$, siendo los alemanes los principales compradores con un $48 \%$, los italianos con el $17 \%$, y en menor medida los japoneses. ${ }^{63}$ Sin embargo, cuando se suscitó la Segunda Guerra Mundial, los Estados Unidos estuvieron interesados en derogar el embargo comercial para, por un lado, dejar sin proveedor de petróleo a los alemanes y, por el otro, solicitar a México su cooperación para el aprovisionamiento de mano de obra y materias primas, entre ellas petróleo crudo, con el objetivo de solventar el aparato productivo estadounidense durante la guerra. Esto, a cambio de reducir a un $10 \%$ la deuda pública directa, lo equivalente a 49.6 millones de dólares, de 509.5 que se pedían inicialmente. ${ }^{64}$

${ }^{62}$ Friedrich Katz, "México y Austria en 1938”, Revista Mexicana de Política Exterior, núm. 20 (julio-septiembre, 1988): 18-23.

${ }^{63}$ Katz, 18-23.

${ }^{64}$ Cárdenas, La hacienda pública y la política económica, 1929-1958, 98-99.

Sillares, vol. 1, núm. 1, 2021

DOI: https://doi.org/10.29105/sillares1.1-2 
La intensificación del comercio entre México y Estados Unidos durante esa guerra aumentó las importaciones en el país. La demanda de productos generó la necesidad de construir nuevos buques mercantes de mayor capacidad. Si en 1938 se construían barcos que pudieran transportar un máximo de 250 toneladas, durante el conflicto bélico se fabricaron embarcaciones con capacidad de 750 toneladas que recorrían todo el Golfo de México. ${ }^{65}$ De esta manera, durante el conflicto bélico la producción y reparación de barcos se intensificó, por lo que Appedole se vio en la necesidad de aumentar sus empleados y establecer tres turnos de trabajo divididos durante las 24 horas del día, razón por la que el empresario libanés ordenó la construcción de tres hoteles conectados a los jardines de su casa, para darle alojamiento a todos sus trabajadores, muchos de ellos libaneses. ${ }^{66}$ Fue así que, gracias a la coyuntura de auge comercial, Astilleros de Tampico se posicionó como la principal empresa en construcción de buques que impulsó el desarrollo de la industria naviera en México.

\footnotetext{
${ }^{65}$ Nasr y Abud, Directorio Libanés: censo general de las colonias libanesapalestina-siria residentes en la República Mexicana.

${ }^{66}$ Entrevista realizada a Max Appedole, 5 de junio de 2020.
}

Sillares, vol. 1, núm. 1, 2021

DOI: https://doi.org/10.29105/sillares1.1-2 


\section{Inmigración y formación}

Para los años de la posguerra, Appedole ya había acumulado grandes cantidades de capital que fueron heredadas a sus hijos, quedándose el primogénito como el accionista mayoritario de Astilleros. No obstante, lo mismo sucedió con las otras familias de empresarios libaneses, ya que a raíz de la devaluación del peso en 1948 se hizo presente un panorama de inflación en el mercado internacional, lo que hizo más difícil la compra de productos en el extranjero. Esto se tradujo en un tipo de modelo de sustitución de importaciones y en un proceso de defensa de las industrias nacionales, evidenciando la necesidad de adquirir los productos que se fabricaban en el país, lo que dio impulso a las compañías textiles y de calzado en México, ${ }^{67}$ en las cuales estaban involucrados los libaneses. Fue un mecanismo nacional en respuesta a una coyuntura internacional que permitió que estos inmigrantes experimentaran un nuevo impulso en su ascenso social y acumulación de capital, como fue el caso de los Nader.

De esta manera, tanto la familia Nader como la Appedole, Abisulaiman y Schekaiban, mostraron una sucesión generacional en la década de 1950. Es durante estos años que se observa el final

\footnotetext{
${ }^{67}$ Cárdenas, La hacienda pública y la política económica, 1929-1958, 92.

Sillares, vol. 1, núm. 1, 2021

DOI: https://doi.org/10.29105/sillares1.1-2
} 
de la primera generación en cuanto a dirección empresarial, para ser ocupada por las segundas generaciones. No obstante, hubieron casos en que - gracias al capital familiar acumulado por décadas - los hijos decidieron fundar su propia empresa como fue el caso de Neder Nader Habib quien en 1956 funda en Tampico la empresa UNITAM, S.A. de C.V, dedicada a la fabricación de uniformes para trabajadores de empresas públicas y privadas, primero de cobertura regional, para después convertirse en una de las empresas más importantes de su ramo en el país, contando actualmente con más de 42 sucursales distribuidas a lo largo de la república mexicana, siendo Jesús Nader Nasrallah (hijo de Neder, descendiente de la tercera generación) quien actualmente está a cargo de la empresa familiar.

\section{Conclusiones}

Son dos los ejes estructurales expuestos en el presente artículo que es menester, a modo de conclusión, reiterar. El primero es el relacionado con el proceso de acumulación de capital que fue originado por diversos factores. En primer lugar, por la implementación de un sistema de ventas que recurrió al crédito a través del pago en abonos, el cual brindó facilidades de compra 


\section{Inmigración y formación}

con productos a bajo costo para un nuevo mercado: el del campesino y obrero pobre del campo y la ciudad. En segundo lugar, podríamos mencionar la socialización del buhonero libanés con el pueblo a través del comercio ambulante, aspecto que dotó al migrante de conocimiento sobre las necesidades de sus clientes, llevándolo a incorporar nuevos productos para atender la demanda y obtener una mayor capacidad de venta. En tercer lugar, se destaca una ética de trabajo constante enfocada en el ahorro y el bajo consumo, con la visión de adquirir movilidad social ascendente, pasando del comercio informal y ambulante al formal, con el establecimiento de una tienda, almacén o fábrica. Otros dos factores importantes que se pueden mencionar son el generar empleo utilizando a los nuevos inmigrantes como fuerza de trabajo para acrecentar los negocios; y aprovechar las coyunturas de crisis económicas para acumular mayor capital.

Con respecto al segundo eje estructural, el de la organización empresarial, este significó la manera no sólo de administrar el capital, sino de preservarlo y heredarlo a las siguientes generaciones. A través de la empresa, el capital económico se transformó en un patrimonio familiar en donde la 
permanencia de la misma significó un seguro de vida para garantizar el bienestar de la familia libanesa, no sólo de la generación fundadora, sino de las siguientes, un elemento que podemos observar hasta la actualidad. Es por ello que los patrones éticos y la estructura patrilocal y patrilineal se trasladaron a la dirección, administración y sucesión de la empresa familiar. De esta manera, tanto las formas de acumulación de capital anteriormente mencionadas, como la aplicación de la estructura familiar en el manejo empresarial, constituyeron la ecuación que dio como resultado a la formación del empresariado libanés en Tampico durante la primera mitad del siglo XX.

\section{Referencias}

\section{Archivo}

Archivo General de la Nación (México)

Archivo General de Notarías del Estado de Tamaulipas

Archivo Histórico de Tampico

Archivo Libanés de la Ciudad de México

Sillares, vol. 1, núm. 1, 2021

DOI: https://doi.org/10.29105/sillares1.1-2 


\section{Bibliografía}

Alfaro-Velcamp, Theresa. So far from Allah, so close to Mexico: Middle Eastern immigrants in modern Mexico. Austin: University of Texas Press, 2007.

Alonso Palacios, Angelina. Los libaneses y la industria textil en Puebla. México: Centro de Investigaciones y Estudios Superiores en Antropología Social, 1983.

Cárdenas, Enrique. La hacienda pública y la política económica, 1929-1958. México: Fondo de Cultura Económica, 1994.

Censo general de la República Mexicana verificado el 28 de octubre de 1900, conforme a las instrucciones de la Dirección General de Estadística a cargo del Dr. Antonio Peñafiel. México: Secretaría de Fomento, 1901

Colin, Jean Philippe, Christophe Blanchot, Enrique Vázquez y Hermilio Navarro. "Reforma agraria, dinámicas organizativas, y prácticas agrarias. El caso de Graciano Sánchez, Tamaulipas, México". En Políticas y regulaciones agrarias: dinámicas de poder y juegos de actores en torno a la tenencia de la tierra, coord. por Éric Leonard y André Quesnel, 73-106. México: Centro de Investigaciones y Estudios Superiores de Antropología Social, 2003.

Dávila Valdés, Claudia. "Socio-Economic Trajectory and Geographical Mobility of Lebanese and Koreans: From Motul to Mérida". Migraciones Internacionales 8, núm. 2 (julio-diciembre 2015): 103-131. 
Díaz de Kuri, Martha y Lourdes Macluf. De Líbano a México: crónica de un pueblo emigrante. México: Talleres de Gráfica, Creatividad y Diseño, 1995.

Gleizer, Daniela. "Las relaciones entre México y el Tercer Reich, 1933-1941", Tzintzun. Revista de Estudios Históricos, núm. 64 (julio-diciembre 2016): 223-258.

González Navarro, Moisés. Los extranjeros en México y los mexicanos en el extranjero, 1821-1970. Vol. 2. México: El Colegio de México, 1994.

Hernández Elizondo, Roberto. Empresarios extranjeros, comercio y petróleo en Tampico y la Huasteca (18901930). México: Universidad Autónoma de Tamaulipas, Plaza y Valdés S.A. de C.V., 2006.

Inclán Rubio, Rebeca. "Inmigración libanesa en la Cd. de Puebla 1890-1930: proceso de aculturación". Tesis de licenciatura, Universidad Nacional Autónoma de México, 1978.

Katz, Friedrich. "México y Austria en 1938", Revista Mexicana de Política Exterior, núm. 20 (julio-septiembre, 1988): 18-23.

Marín Guzmán, Roberto. "Las causas de la emigración libanesa durante el siglo XIX y principios del XX. Un estudio de historia económica y social", Estudios de Asia y África 31, núm. 3 (septiembre-diciembre, 1996): 557-606.

Martínez Assad, Carlos. "Los libaneses inmigrantes y sus lazos culturales desde México", Dimensión Antropológica 15, vol. 44 (septiembre-diciembre, 2008): 133-155.

México. Departamento de la Estadística Nacional. Censo general de habitantes: 30 de noviembre de 1921. México: Talleres Gráficos de la Nación, 1925. 
Morales Meléndez, Víctor Hugo y Luis Ricardo López Figueroa. "La política de inmigración de México. Interés nacional e imagen internacional", Foro Internacional XXXIX-1, núm. 155 (enero-marzo, 1999): 65-92.

Nasr, Julián y Salim Abud. Directorio Libanés: censo general de las colonias libanesa-palestina-siria residentes en la República Mexicana. México: Talleres Linotipográficos "Casa Velux", 1948.

Ortega Velázquez, Elisa. "La consolidación histórica de la migración irregular en Estados Unidos: leyes y políticas migratorias restrictivas, ineficaces y demagógicas", Norteamérica 12, núm. 1 (enero-junio 2017): 197-231.

Pastor, Camila. The Mexican Mahjar: Transnational Maronites, Jews, and Arabs under the French Mandate. Austin: University of Texas Press, 2017.

Petit, Lorenza. "El mahyar mexicano. Producción literaria y periodística de los inmigrantes árabes y sus descendientes". Tesis de doctorado, Universidad Autónoma de Madrid, 2017. https://repositorio.uam.es/handle/10486/681503

Pizaña-Grimaldo, Oscar Israel. "Del Máshrek hacia México: La formación de la colonia libanesa en Tampico, 18821948”, Revista de Filosofía y Cotidianidad 4, núm. 11 (junio 2018): 20-32.

Quinto censo de población, 15 de mayo de 1930. Vol. VII, Tomo XXVII: Estado de Tamaulipas (México: Secretaría de la Economía Nacional, 1933). 
Ramírez Carrillo, Luis Alfonso. De cómo los libaneses conquistaron la Península de Yucatán: migración, identidad étnica y cultura empresarial. Mérida: Universidad Nacional Autónoma de México, Centro Peninsular en Humanidades y Ciencias Sociales, 2012.

Ramírez Carrillo, Luis Alfonso. "Identidad persistente y nepotismo étnico: movilidad social de inmigrantes libaneses en México", Nueva Antropología. Revista de Ciencias Sociales 31, núm. 89 (julio-diciembre 2018): 9-23.

Romero Ibarra, María Eugenia, "Del pequeño almacén a los negocios financieros. Tres sucesiones exitosas en una familia empresaria: Grupo Coppel, 1940-2010", en Familias empresariales en México. Sucesión generacional y continuidad en el siglo $X X$, coord. por Araceli Almaraz y Luis Alfonso Ramírez, 227-254. Tijuana: El Colegio de la Frontera Norte, 2018.

Tercer censo de población de los Estados Unidos Mexicanos, verificado el 27 de octubre de 1910. México: Secretaría de Hacienda, Departamento de Fomento, 1918.

Vázquez Soberano, Raymundo. "Los sirio-libaneses en Tabasco.

La conformación de un grupo dominante: 1910-1935". Tesis de doctorado, Universidad Veracruzana, 2016. https://cdigital.uv.mx/handle/123456789/41693

Zéraoui, Zidane, "Los árabes en México: entre la integración y el arabismo", Revista Estudios, núms. 12-13 (juliodiciembre 1995): 13-39. 